\title{
Heat and Acid Leach Treatments to Lower Phosphorus Levels in Goethitic Iron Ores
}

\author{
Michael John FISHER-WHITE, Roy Randall LOVEL* and Graham Jeffrey SPARROW \\ CSIRO Process Science and Engineering, Box 312, Clayton South, Victoria, 3169 Australia.
}

(Received on May 2, 2012; accepted on May 28, 2012)

\begin{abstract}
Phosphorus associated with goethite in high-phosphorus ( $>0.10$ mass $\% \mathrm{P}$ ) iron ores was lowered to below 0.075 mass $\%$ P with a heat treatment at 300 or $350^{\circ} \mathrm{C}$ for $1 \mathrm{~h}$ followed by a sulphuric acid $\left(\mathrm{H}_{2} \mathrm{SO}_{4}\right)$ leach. This phosphorus removal was associated with a sample weight loss of 10-20 mass\% due to dissolution of iron oxides. After heating at $900^{\circ} \mathrm{C}$ for $1 \mathrm{~h}$, a sulphuric acid leach resulted in similar phosphorus removal but with dissolution of less than 3 mass \% of the sample.

The weight losses in the leach are associated with phase changes of the phosphorus-containing goethite phase during heating. Heating at 300 or $350^{\circ} \mathrm{C}$ resulted in conversion of the goethite into an intermediate hematite phase (protohematite), while heating at $900^{\circ} \mathrm{C}$ gave a dense hematite phase. Compared with goethite in the ore, the more porous protohematite phase was more soluble in the sulphuric acid resulting in dissolution of iron with the phosphorus, while the dense hematite phase was much less soluble and little iron was dissolved in the leach.

Leaching at 25 mass $\%$ solids for $3 \mathrm{~h}$ at $60^{\circ} \mathrm{C}$, at a pH of 0.5 or lower, gave significant lowering of phosphorus levels. Leaches were with $0.1-1 \mathrm{M} \mathrm{H}_{2} \mathrm{SO}_{4}$; the concentration of acid required depended on the amount of phosphorus to be removed. Recycling of the acid leach liquor four times did not show evidence for precipitation of phosphorus and resulted in leach solutions with up to $1 \mathrm{~g} / \mathrm{L} \mathrm{P}$ and $134 \mathrm{~g} / \mathrm{L} \mathrm{Fe}$.
\end{abstract}

KEY WORDS: phosphorus; goethite; heat treatment; sulphuric acid.

\section{Introduction}

Phosphorus in feedstock for blast furnaces affects the quality of the steel produced, ${ }^{1)}$ and while methods for removing phosphorus from molten iron exist, ${ }^{2)}$ it is beneficial to operations if phosphorus levels are low prior to smelting and melting.

Market specifications for phosphorus in iron ore exported from Australia are around 0.075 mass $\% \mathrm{P}^{3)}$ The bulk of current production is a blend of low-phosphorus $(<0.07$ mass $\%$ P) martite-hematite ores and high-phosphorus martitegoethitic ores. ${ }^{4)}$ As discussed previously, ${ }^{5)}$ it has been estimated $^{6)}$ that there are 8.02 billion tonnes of high phosphorus ore $(>0.10$ mass $\% \mathrm{P})$ in Australian deposits. The development of a successful process to remove phosphorus from the high phosphorus ore would significantly extend the reserves of high grade low phosphorus Australian ores. ${ }^{3)}$

In Australian ores from the Pilbara, most of the phosphorus observed in the iron ore is associated with goethite. ${ }^{4,7,8)}$ This phosphorus is considered to be mainly located in a texturally distinct goethite phase (termed ochreous goethite) that is commonly associated with high levels of other impurity elements such as silicon and aluminium. ${ }^{7,8)}$ While high levels of phosphorus have been observed in some samples of vitreous goethite, where dehydration and recrystallisation of the goethite has occurred in natural deposits, phosphorus levels in this type of deposit are generally lower. ${ }^{9}$

Physical separation methods ${ }^{9)}$ and simple leaching processes $^{5,10)}$ do not remove sufficient phosphorus from the high phosphorus ores to meet market specifications of 0.075 mass $\%$ P. However, a heat treatment makes the phosphorus available for removal in a subsequent acid leaching step $^{2,11)}$ as shown by the heating of Australian iron ores at $1000-1300^{\circ} \mathrm{C}$ in air and leaching with sulphuric acid that has been reported to lower their phosphorus levels to below 0.06 mass $\% \mathrm{P}^{3,12,13)}$ Also, after heating iron ores with various additives (the best being alkaline earth chlorides) at $500-1200^{\circ} \mathrm{C}$ (with $900^{\circ} \mathrm{C}$ the optimum), an acid leach has been shown to lower phosphorus levels from 0.42 to 0.02 0.08 mass $\% \mathrm{P}$ depending on the additive. ${ }^{14)}$ In our previous work, ${ }^{5,10)}$ a heat treatment at $300^{\circ} \mathrm{C}$ followed by a caustic leach was shown to lower the phosphorus content of high phosphorus Australian iron ores to marketable levels.

In this paper, results for the removal of phosphorus from three iron ore samples with an acid leach after a heat treatment are reported. These results expand on our previous acid leaching results ${ }^{15)}$ and enable the development of a comprehensive account of the influences of thermal treatment and acid leaching conditions on phosphorus removal from iron ore.

* Corresponding author: E-mail: roy.lovel@csiro.au

DOI: http://dx.doi.org/10.2355/isijinternational.52.1794 


\section{Experimental}

\subsection{Samples}

Three West Australian high phosphorus iron ore fines ($6.3 \mathrm{~mm}$ ) designated ore 1 , ore 2 and ore 5 were used in this work. Ore 1 and ore 2 were examples of high phosphorus Brockman Iron Formation in the Pilbara and ore 5 was a high phosphorus ore from within the Yilgarn Iron Province. Representative samples for the test work were prepared by splitting a sub-sample from the ores as received, crushing and grinding the sub-sample to less than $2 \mathrm{~mm}$ to homogenise the sample, and then splitting small samples for individual tests from the $-2 \mathrm{~mm}$ material.

The ores contained 0.146 mass $\% \mathrm{P}$ (ore 1 ), 0.123 mass $\%$ $\mathrm{P}$ (ore 2) and 0.161 mass $\% \mathrm{P}$ (ore 5) with iron contents of 62.0, 62.1 and 64.2 mass\% Fe, respectively (Table 1). The XRF assays in Table 1 indicated that the compositions of ore 1 and ore 2 were similar and they contained higher levels of impurities (3.07 and 3.22 mass\% $\quad \mathrm{SiO}_{2}$ and 2.27 and 2.18 mass $\% \mathrm{Al}_{2} \mathrm{O}_{3}$, respectively) than ore 5 (0.40 mass $\%$ $\mathrm{SiO}_{2}$ and 0.11 mass $\% \mathrm{Al}_{2} \mathrm{O}_{3}$ ).

Quantitative XRD data for the samples ${ }^{5)}$ indicate the iron minerals present in ore 1 and ore 2 were goethite (3539 mass \%) and hematite (55-60 mass\%). A small amount of kaolinite (6 mass \%), an aluminosilicate clay mineral, was also identified in ore 1 and ore 2 . Ore 5 was composed mainly of goethite (66 mass\%) and hematite (31 mass $\%)$ with a small amount of magnetite ( 3 mass $\%$ ).

\subsection{Methods}

Small samples of the ores (1-2 g) were heated in a platinum boat in a tube furnace in air at the required temperature, usually for $1 \mathrm{~h}$. After the required time at temperature the sample was allowed to cool in the furnace. When larger samples were used $(70 \mathrm{~g})$, the sub-samples were heated in a platinum dish in a muffle furnace in air at the required temperature $\left( \pm 10^{\circ} \mathrm{C}\right)$ for the required time. Generally, the sample was then removed from the furnace and allowed to cool in air before leaching or analysis. The heated samples were free flowing and were used for leaching without further processing.

The heated samples were leached in a glass reaction vessel fitted with a stirrer, a condenser and a thermocouple. The leachant and sample were heated to temperature with an external heating mantle and then leached for the required time. After leaching, the liquor was cooled and the leach product was filtered, washed with water, filtered and dried for analysis.

Solid samples for analysis were ground in a tungsten carbide ball-mill and elemental analyses were conducted on fused beads using a wavelength dispersive X-ray fluorescence (XRF) spectrometer using the program developed in CSIRO for iron ore analyses.

The concentration of phosphorus and iron in the leach solutions were determined using Inductively Coupled Plasma Optical Emission Spectroscopy (ICP OES).

\section{Results}

\subsection{Effect of Heating Conditions}

Heating the ores prior to a caustic leach has been shown to increase the amount of phosphorus removed. ${ }^{5)}$ Similarly, a heat treatment prior to acid leaching increases the amount of phosphorus removed and Fig. 1 indicates that after the same heat treatment of ore 1, the products from leaches with $1 \mathrm{M} \mathrm{NaOH}$ and $0.1 \mathrm{M} \mathrm{H}_{2} \mathrm{SO}_{4}$ contained similar phosphorus levels as did those from leaches with $5 \mathrm{M} \mathrm{NaOH}$ and $0.5 \mathrm{M}$ $\mathrm{H}_{2} \mathrm{SO}_{4}$. It can be seen that phosphorus removal increased significantly with heating temperatures of 275 to $300^{\circ} \mathrm{C}$. Between $350-800^{\circ} \mathrm{C}$ there was little variation in the level of phosphorus removal, and greater amounts were removed when the ore was heated at $800^{\circ} \mathrm{C}$ and above.

The increase in phosphorus removal after heating at about $300^{\circ} \mathrm{C}$ and heating to above $800^{\circ} \mathrm{C}$ is considered to be associated with phase changes in the phosphorus-containing goethite fraction of the ores (see the Discussion). Previous

Table 1. Effects of leaching conditions on impurity removal from the as received ore samples.

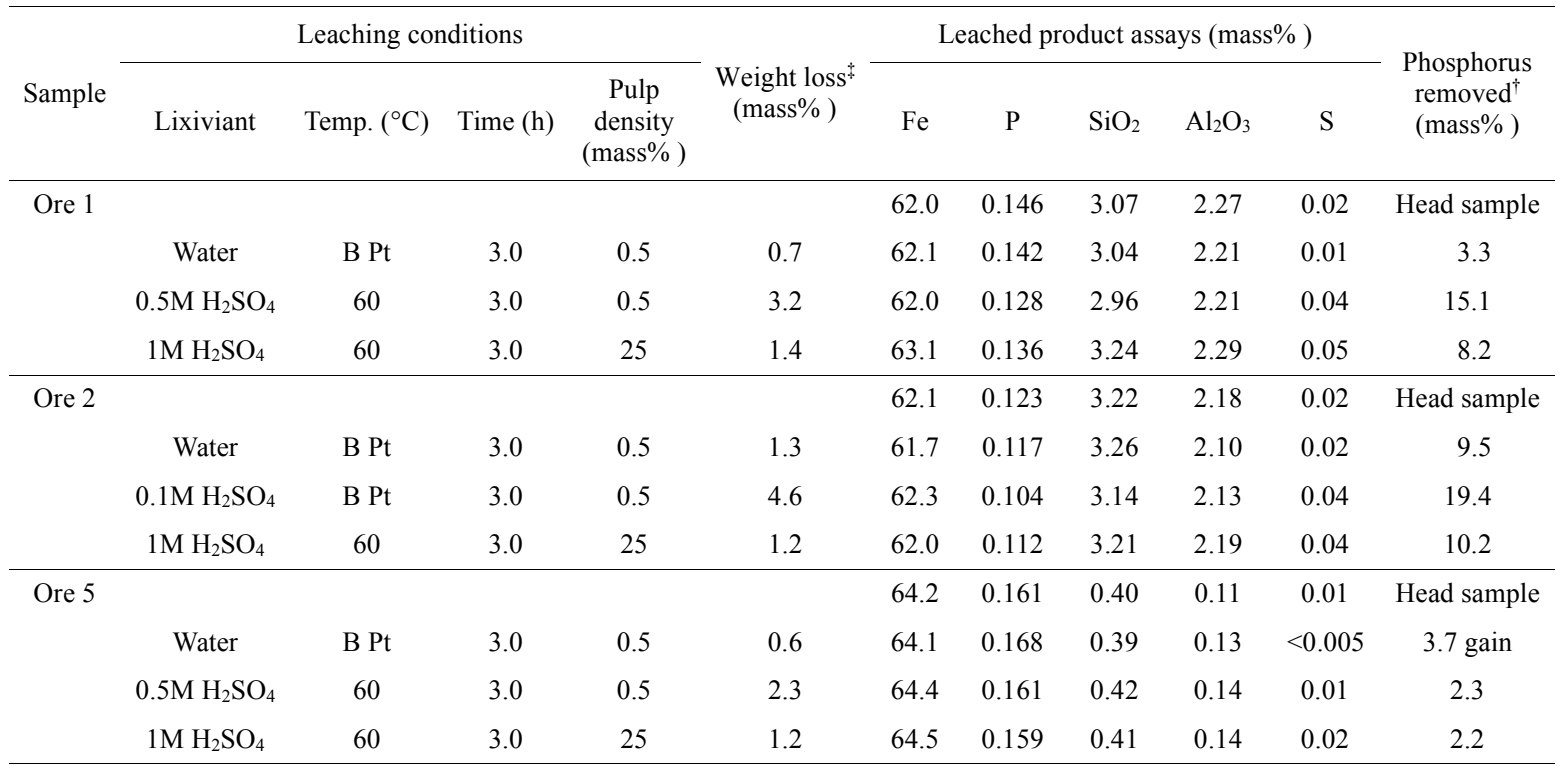

\footnotetext{
\# Weight loss in the leach based on the solids added to the leach and the residue weight.
}

${ }^{\dagger}$ Based on the head assay, the weight before heating and the residue assay and weight. 


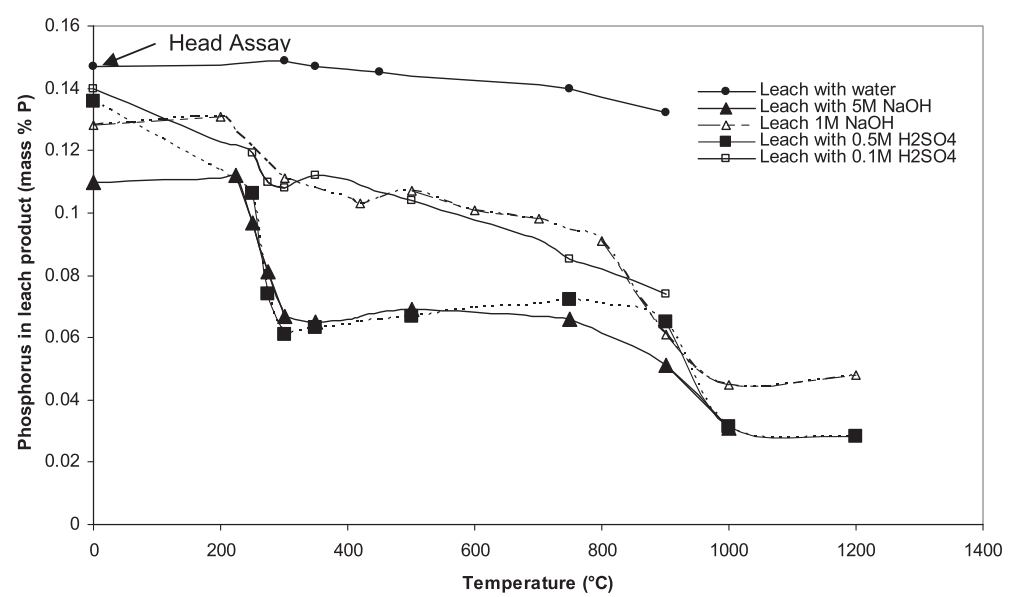

Fig. 1. Effect of heating temperature on phosphorus levels in leach products from ore 1 heated and then leached with sodium hydroxide and sulphuric acid at 0.5 mass $\%$ solids ( $\mathrm{NaOH}$ data from Ref. 5).

Table 2. Effects on impurity removal from the ore samples of a heat treatment at 300 or $350^{\circ} \mathrm{C}$ for $1 \mathrm{~h}$ and a leach with sulphuric acid for $3 \mathrm{~h}$ at 0.5 mass $\%$ solids.

\begin{tabular}{|c|c|c|c|c|c|c|c|c|c|c|}
\hline \multirow{2}{*}{ Sample } & \multirow{2}{*}{$\begin{array}{l}\text { Heating temp. } \\
\left({ }^{\circ} \mathrm{C}\right)\end{array}$} & \multicolumn{2}{|c|}{ Leaching conditions } & \multirow{2}{*}{$\begin{array}{l}\text { Weight loss } \\
\text { (mass\%) }\end{array}$} & \multicolumn{5}{|c|}{ Leached product assays (mass\%) } & \multirow{2}{*}{$\begin{array}{c}\text { Phosphorus } \\
\text { removed }^{\dagger} \\
\text { (mass\%) }\end{array}$} \\
\hline & & Lixiviant & Temp. $\left({ }^{\circ} \mathrm{C}\right)$ & & $\mathrm{Fe}$ & $\mathrm{P}$ & $\mathrm{SiO}_{2}$ & $\mathrm{Al}_{2} \mathrm{O}_{3}$ & $\mathrm{~S}$ & \\
\hline \multirow[t]{3}{*}{ Ore 1} & & & & & 62.0 & 0.146 & 3.07 & 2.27 & 0.02 & Head sample \\
\hline & 300 & $0.1 \mathrm{M} \mathrm{H}_{2} \mathrm{SO}_{4}$ & 60 & 6.3 & 63.4 & 0.108 & 2.96 & 1.90 & 0.18 & 33.4 \\
\hline & 300 & $0.5 \mathrm{M} \mathrm{H}_{2} \mathrm{SO}_{4}$ & 60 & 22.9 & 64.5 & 0.061 & 3.06 & 1.77 & 0.12 & 68.8 \\
\hline \multirow[t]{4}{*}{ Ore 5} & & & & & 64.2 & 0.161 & 0.40 & 0.11 & 0.01 & Head sample \\
\hline & 350 & $0.25 \mathrm{M} \mathrm{H}_{2} \mathrm{SO}_{4}$ & 60 & 4.85 & 66.3 & 0.141 & 0.39 & 0.09 & 0.31 & 21.6 \\
\hline & 350 & $0.5 \mathrm{M} \mathrm{H}_{2} \mathrm{SO}_{4}$ & 60 & 10.8 & 66.3 & 0.118 & 0.34 & 0.08 & 0.35 & 38.2 \\
\hline & 350 & $1 \mathrm{M} \mathrm{H}_{2} \mathrm{SO}_{4}$ & 60 & 18.0 & 66.0 & 0.090 & 0.57 & 0.08 & 0.33 & 56.9 \\
\hline
\end{tabular}

${ }^{*}$ Weight loss in the leach based on the solids added to the leach and the residue weight.

${ }^{\dagger}$ Based on the head assay, the weight before heating and the residue assay and weight.

work ${ }^{5)}$ indicated that the phase changes were complete within $30 \mathrm{~min}$ for a heating temperature of $300^{\circ} \mathrm{C}$, significantly less than the $1 \mathrm{~h}$ heating time generally used in this work.

\subsection{Effect of Leaching Conditions}

The effect of the leaching conditions to lower phosphorus levels in the ores was determined using sub-samples of the ores and samples heated at 300 or $350^{\circ} \mathrm{C}$ and at $900^{\circ} \mathrm{C}$ prior to leaching.

\subsubsection{Acid and Water Leaching of the Ores}

Leaching ore 1 with boiling water removed little phosphorus and a leach with $1 \mathrm{M} \mathrm{H}_{2} \mathrm{SO}_{4}$ at 25 mass\% solids removed almost 10 mass\% of the phosphorus (Table 1). With ore 2, 10 mass $\%$ of the phosphorus was removed in both the water and $1 \mathrm{M} \mathrm{H}_{2} \mathrm{SO}_{4}$ leaches. There was little loss of weight of the samples in the water and acid leaches and the resulting leach products for ore 1 and ore 2 contained 0.136 mass $\% \mathrm{P}$ and 0.112 mass $\% \mathrm{P}$, respectively. Acid leaching at a low solids pulp density of 0.5 mass $\%$ solids removed 15 mass\% of the phosphorus from ore 1 and 19 mass $\%$ from ore 2 (Table 1).

Water and acid leaching of ore 5 removed little phosphorus from the sample (Table 1).

Leaching with water or acid was ineffective in mobilising silica or alumina from ore 1 , ore 2 or ore 5 .

\subsubsection{Heating at 300 or $350^{\circ} \mathrm{C}$ Followed by an Acid Leach}

Acid leaching after a heat treatment gave better phosphorus removal with the amount of phosphorus removed increasing with increasing acid concentration. For ore 1, heated at $300^{\circ} \mathrm{C}$, the results in Table 2 show that a leach with $0.1 \mathrm{M} \mathrm{H}_{2} \mathrm{SO}_{4}$ gave a product with 0.108 mass $\% \mathrm{P}$, while a leach with $0.5 \mathrm{M} \mathrm{H}_{2} \mathrm{SO}_{4}$ gave 0.061 mass $\%$ P. Similarly, increasing acid concentration increased phosphorus removal from ore 2 heated at $300^{\circ} \mathrm{C}$ (Table 3) and ore 5 heated at $350^{\circ} \mathrm{C}$ (Table 2). A leach of ore 5 , the ore with the highest initial phosphorus content, with $0.5 \mathrm{M} \mathrm{H}_{2} \mathrm{SO}_{4}$ gave a product with 0.118 mass $\% \mathrm{P}$ while a leach of ore 1 under the same conditions with only $0.1 \mathrm{M} \mathrm{H}_{2} \mathrm{SO}_{4}$ gave a product with 0.108 $\operatorname{mass} \% \mathrm{P}$.

Increasing the solids pulp density in the leach required higher acid concentrations to achieve a similar levels of phosphorus removal. For heated ore 2, a leach with $0.1 \mathrm{M}$ $\mathrm{H}_{2} \mathrm{SO}_{4}$ at 0.5 mass $\%$ solids gave a product with 0.062 mass\% $\mathrm{P}$ while an acid concentration of $1 \mathrm{M} \mathrm{H}_{2} \mathrm{SO}_{4}$ was required to obtain a product with 0.066 mass $\% \mathrm{P}$ in a leach at 25 mass\% solids (Table 3).

The results in Table 3 for leaches at 25 mass $\%$ solids indicate that a leaching temperature of $60^{\circ} \mathrm{C}$ was satisfactory and only a small increase in phosphorus removal was obtained with a higher leaching temperature. The results in Table 3 also show that longer leaching times resulted in 
Table 3. Effects of sulphuric acid leaching conditions on impurity removal from ore 2 heated at $300^{\circ} \mathrm{C}$ for $1 \mathrm{~h}$.

\begin{tabular}{|c|c|c|c|c|c|c|c|c|c|c|}
\hline \multicolumn{4}{|c|}{ Leaching conditions } & \multirow[b]{2}{*}{$\begin{array}{l}\text { Weight loss }{ }^{\ddagger} \\
\text { (mass\%) }\end{array}$} & \multicolumn{5}{|c|}{ Leached product assays (mass\%) } & \multirow[b]{2}{*}{ 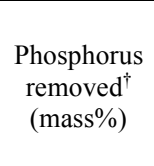 } \\
\hline Lixiviant & $\begin{array}{c}\text { Temp. } \\
\left({ }^{\circ} \mathrm{C}\right)\end{array}$ & Time (h) & $\begin{array}{c}\text { Pulp } \\
\text { density } \\
\text { (mass\% ) }\end{array}$ & & $\mathrm{Fe}$ & $\mathrm{P}$ & $\mathrm{SiO}_{2}$ & $\mathrm{Al}_{2} \mathrm{O}_{3}$ & $\mathrm{~S}$ & \\
\hline- & - & - & - & - & 62.1 & 0.123 & 3.22 & 2.18 & 0.02 & Head sample \\
\hline \multicolumn{11}{|c|}{ Effect of acid concentration, leach pulp density } \\
\hline Water & $\mathrm{BPt}$ & 3.0 & 0.5 & 1.3 & 63.3 & 0.127 & 3.25 & 2.32 & 0.01 & 0 \\
\hline $0.01 \mathrm{M} \mathrm{H}_{2} \mathrm{SO}_{4}$ & $\mathrm{~B} \mathrm{Pt}$ & 3.0 & 0.5 & 3.3 & 64.2 & 0.116 & 2.95 & 1.86 & 0.10 & 12.1 \\
\hline $0.1 \mathrm{M} \mathrm{H}_{2} \mathrm{SO}_{4}$ & $\mathrm{~B}$ Pt & 3.0 & 0.5 & 19.8 & 64.8 & 0.062 & 3.31 & 1.87 & 0.07 & 61.1 \\
\hline $0.1 \mathrm{M} \mathrm{H}_{2} \mathrm{SO}_{4}$ & $\mathrm{~B} P \mathrm{Pt}$ & 3.0 & 10 & 1.2 & 64.0 & 0.123 & 3.15 & 1.94 & 0.10 & 4.7 \\
\hline $0.5 \mathrm{M} \mathrm{H}_{2} \mathrm{SO}_{4}$ & $\mathrm{~B}$ Pt & 3.0 & 25 & 0.7 & 63.1 & 0.105 & 3.28 & 2.08 & 0.20 & 18.5 \\
\hline $1 \mathrm{M} \mathrm{H}_{2} \mathrm{SO}_{4}$ & $\mathrm{~B}$ Pt & 3.0 & 25 & 13.7 & 64.2 & 0.066 & 3.55 & 1.79 & 0.11 & 55.4 \\
\hline \multicolumn{11}{|c|}{ Effect of leaching temperature } \\
\hline $1 \mathrm{M} \mathrm{H}_{2} \mathrm{SO}_{4}$ & 21 & 3.0 & 25 & 0 & 63.2 & 0.114 & 3.16 & 2.08 & 0.13 & 10.7 \\
\hline $1 \mathrm{M} \mathrm{H}_{2} \mathrm{SO}_{4}$ & 40 & 3.0 & 25 & 3.5 & 63.0 & 0.097 & 3.14 & 2.04 & 0.18 & 26.7 \\
\hline $1 \mathrm{M} \mathrm{H}_{2} \mathrm{SO}_{4}$ & 60 & 3.0 & 25 & 9.6 & 63.3 & 0.078 & 3.26 & 1.92 & 0.21 & 44.8 \\
\hline $1 \mathrm{M} \mathrm{H}_{2} \mathrm{SO}_{4}$ & 80 & 3.0 & 25 & 10.9 & 63.7 & 0.074 & 3.22 & 1.83 & 0.18 & 48.3 \\
\hline $1 \mathrm{M} \mathrm{H}_{2} \mathrm{SO}_{4}$ & $\mathrm{~B} \mathrm{Pt}$ & 3.0 & 25 & 13.7 & 64.2 & 0.066 & 3.55 & 1.79 & 0.11 & 55.4 \\
\hline \multicolumn{11}{|c|}{ Effect of leaching time } \\
\hline $1 \mathrm{M} \mathrm{H}_{2} \mathrm{SO}_{4}$ & 60 & 0.25 & 25 & 2.0 & 63.4 & 0.108 & 3.32 & 2.11 & 0.15 & 17.1 \\
\hline $1 \mathrm{M} \mathrm{H}_{2} \mathrm{SO}_{4}$ & 60 & 1.0 & 25 & 5.8 & 63.8 & 0.094 & 3.20 & 2.01 & 0.16 & 30.7 \\
\hline $1 \mathrm{M} \mathrm{H}_{2} \mathrm{SO}_{4}$ & 60 & 3.0 & 25 & 9.6 & 63.3 & 0.078 & 3.26 & 1.92 & 0.21 & 44.8 \\
\hline
\end{tabular}

${ }^{*}$ Weight loss in the leach based on the solids added to the leach and the residue weight.

${ }^{\dagger}$ Based on the head assay, the weight before heating and the residue assay and weight.

higher levels of phosphorus removal and higher sample weight losses from ore heated at $300^{\circ} \mathrm{C}$. A leaching time of $3 \mathrm{~h}$ was used for most tests.

Figure 2, a graph of phosphorus removed during leaching against the sample weight loss in the leach, shows that the amount of phosphorus removed from samples heated at 300 or $350^{\circ} \mathrm{C}$ increased with increasing weight loss. Extrapolation of the lines in Fig. 2 suggests that total phosphorus removal would be associated with a weight loss of around 40 mass \%. For ores 1 and 2 this is close to the 35-39 mass \% goethite in the ores, suggesting that the phosphorus in ores of this type is mainly in the goethite which is soluble in acid after heating. Ore 5, from a different province than ores 1 and 2 , contains 66 mass $\%$ goethite and the results lead us to suspect that this sample contains different forms of goethite with the more soluble forms containing higher levels of phosphorus.

Generating leach products with 0.075 mass\% $\%$ from ores heated at 300 or $350^{\circ} \mathrm{C}$ resulted in dissolution of iron oxides in the sample and iron levels of around $25 \mathrm{~g} / \mathrm{L} \mathrm{Fe}$ in the leach liquors (ore 2) with an associated sample weight loss of 10-20 mass $\%$. In practice, to limit iron losses when leaching ores heated at 300 or $350^{\circ} \mathrm{C}$, the liquors may need to be processed to recover iron from solution.

Ore 1 and ore 2 had appreciably higher silica and alumina levels than ore 5 and the assay data in Tables 2 and 3 for the ores heated at $300^{\circ} \mathrm{C}$ for $1 \mathrm{~h}$ indicate that, while little silica was removed in the acid leach, 30 mass $\%$ of alumina could be removed from ore 1 and 10 mass $\%$ from ore 2 with a $1 \mathrm{M} \mathrm{H}_{2} \mathrm{SO}_{4}$ leach of ores heated to 300 or $350^{\circ} \mathrm{C}$ prior to leaching.

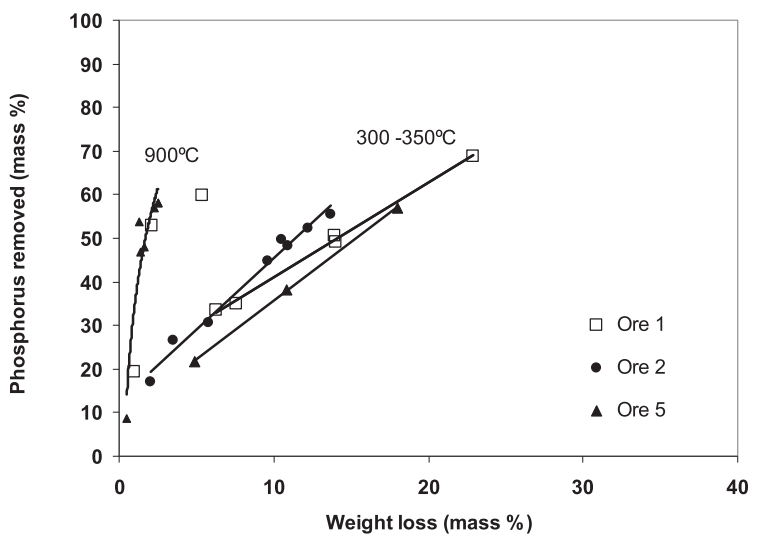

Fig. 2. Relationship between phosphorus removed and the sample weight loss in the sulphuric acid leach for ores heated at 300 or $350^{\circ} \mathrm{C}$ and $900^{\circ} \mathrm{C}$.

In a commercial operation, acid usually would be added at several stages during the leach rather than as a single addition at the start as was done for the leaches presented above. When acid was added during the leach to control the $\mathrm{pH}$ at a specified value, similar trends to those discussed above were observed as shown in Table 4 . With a $\mathrm{pH}$ value of 0.5 or lower, a substantial reduction in phosphorus levels was achieved.

\subsubsection{Heating at $900^{\circ} \mathrm{C}$ Followed by an Acid Leach}

Heating at a higher temperature of $900^{\circ} \mathrm{C}$ resulted in a dense hematite phase being formed from the goethite. ${ }^{16)}$

The results in Table 5 for ore 5 heated at $900^{\circ} \mathrm{C}$ show increasing phosphorus removal with increasing acid concen- 
Table 4. Effects on impurity removal from heated ore samples of a sulphuric acid leach at a constant $\mathrm{pH}$.

\begin{tabular}{|c|c|c|c|c|c|c|c|c|c|c|}
\hline \multirow{2}{*}{ Sample* } & \multirow{2}{*}{$\begin{array}{l}\text { Heating temp. } \\
\qquad\left({ }^{\circ} \mathrm{C}\right)\end{array}$} & \multirow{2}{*}{ Target $\mathrm{pH}$} & \multirow{2}{*}{$\begin{array}{l}\text { Weight loss } \\
\text { (mass } \%)\end{array}$} & \multicolumn{5}{|c|}{ Leached product assays (mass $\%$ ) } & \multirow{2}{*}{$\begin{array}{l}\text { Acid added } \\
\qquad(\mathrm{kg} / \mathrm{t})\end{array}$} & \multirow{2}{*}{$\begin{array}{l}\text { Phosphorus } \\
\text { removed }^{\dagger} \\
(\text { wt \%) }\end{array}$} \\
\hline & & & & $\mathrm{Fe}$ & $\mathrm{P}$ & $\mathrm{SiO}_{2}$ & $\mathrm{Al}_{2} \mathrm{O}_{3}$ & $\mathrm{~S}$ & & \\
\hline \multirow[t]{3}{*}{ Ore 1} & & & & 62.0 & 0.146 & 3.07 & 2.27 & 0.02 & \multicolumn{2}{|c|}{ Head sample } \\
\hline & 300 & 1.0 & 0.9 & 63.6 & 0.140 & 3.06 & 1.93 & 0.19 & 56.6 & 8.6 \\
\hline & 300 & 0.5 & 14.0 & 64.0 & 0.090 & 3.31 & 1.73 & 0.17 & 280 & 49.0 \\
\hline \multirow[t]{4}{*}{ Ore 2} & & & & 62.1 & 0.123 & 3.22 & 2.18 & 0.02 & \multicolumn{2}{|c|}{ Head sample } \\
\hline & Unheated & 0.5 & 2.7 & 62.3 & 0.108 & 3.27 & 2.16 & 0.04 & 9.9 & 14.5 \\
\hline & 300 & 1.0 & 0.3 & 63.8 & 0.123 & 3.20 & 2.10 & 0.19 & 31.5 & 4.2 \\
\hline & 300 & 0.5 & 12.2 & 63.8 & 0.069 & 3.48 & 1.93 & 0.15 & 295 & 52.4 \\
\hline \multirow[t]{4}{*}{ Ore 5} & & & & 64.2 & 0.161 & 0.40 & 0.11 & 0.01 & \multicolumn{2}{|c|}{ Head sample } \\
\hline & 350 & 0.85 & 0 & 66.4 & 0.162 & 0.40 & 0.10 & 0.28 & 48.3 & 4.4 \\
\hline & 350 & 0.5 & 5.8 & 66.5 & 0.136 & 0.39 & 0.08 & 0.32 & 130 & 24.8 \\
\hline & 350 & 0.5 & 8.0 & 67.0 & 0.123 & 0.43 & 0.08 & 0.28 & 280 & 34.1 \\
\hline
\end{tabular}

* Samples were heated at $300^{\circ} \mathrm{C}$ for $1 \mathrm{~h}$ (ore 1 and ore 2 ) or $350^{\circ} \mathrm{C}$ for $1 \mathrm{~h}$ (ore 5 ) and leached at $80^{\circ} \mathrm{C}$ for $3 \mathrm{~h}$ at $25 \mathrm{mass} \%$ solids with the $\mathrm{pH}$ maintained at the selected value by addition of sulphuric acid. Acid addition was required throughout the leach.

Weight loss in the leach based on the solids added to the leach and the residue weight.

$\S$ Based on the weight before heating, and the volume and concentration of sulphuric acid added during the leach.

$\dagger$ Based on the head assay, the weight before heating and the residue assay and weight.

Table 5. Effects on impurity removal from the ore samples of a heat treatment at $900^{\circ} \mathrm{C}$ for $1 \mathrm{~h}$ and a leach with sulphuric acid for $3 \mathrm{~h}$ at 0.5 mass $\%$ solids.

\begin{tabular}{|c|c|c|c|c|c|c|c|c|c|}
\hline \multirow{2}{*}{ Sample } & \multicolumn{2}{|c|}{ Leaching conditions* } & \multirow{2}{*}{$\begin{array}{l}\text { Weight loss }{ }^{\ddagger} \\
(\operatorname{mass} \%)\end{array}$} & \multicolumn{5}{|c|}{ Leached product assays (mass\%) } & \multirow{2}{*}{$\begin{array}{c}\text { Phosphorus } \\
\text { removed }^{\dagger} \\
(\operatorname{mass} \%)\end{array}$} \\
\hline & Lixiviant & $\begin{array}{l}\text { Temp. } \\
\left({ }^{\circ} \mathrm{C}\right)\end{array}$ & & $\mathrm{Fe}$ & $\mathrm{P}$ & $\mathrm{SiO}_{2}$ & $\mathrm{Al}_{2} \mathrm{O}_{3}$ & $\mathrm{~S}$ & \\
\hline \multirow[t]{4}{*}{ Ore 1} & & & & 62.0 & 0.146 & 3.07 & 2.27 & 0.02 & Head sample \\
\hline & Water & 60 & 1.0 & 65.1 & 0.137 & 3.30 & 2.35 & $<0.005$ & 19.5 \\
\hline & $0.1 \mathrm{M} \mathrm{H}_{2} \mathrm{SO}_{4}$ & 60 & 2.1 & 65.6 & 0.074 & 2.99 & 1.54 & 0.02 & 52.8 \\
\hline & $0.5 \mathrm{M} \mathrm{H}_{2} \mathrm{SO}_{4}$ & 60 & 5.4 & 66.2 & 0.065 & 2.96 & 1.40 & 0.04 & 59.9 \\
\hline \multirow[t]{6}{*}{ Ore 5} & & & & 64.2 & 0.161 & 0.40 & 0.11 & 0.01 & Head sample \\
\hline & Water & 60 & 0.5 & 68.8 & 0.158 & 0.44 & 0.13 & $<0.01$ & 8.8 \\
\hline & $0.1 \mathrm{M} \mathrm{H}_{2} \mathrm{SO}_{4}$ & 60 & 1.6 & 68.8 & 0.091 & 0.43 & 0.08 & 0.01 & 48.1 \\
\hline & $0.25 \mathrm{M} \mathrm{H}_{2} \mathrm{SO}_{4}$ & 60 & 1.3 & 68.9 & 0.081 & 0.44 & 0.08 & 0.01 & 53.7 \\
\hline & $0.5 \mathrm{M} \mathrm{H}_{2} \mathrm{SO}_{4}$ & 60 & 2.3 & 69.3 & 0.076 & 0.44 & 0.07 & 0.02 & 56.9 \\
\hline & $1 \mathrm{M} \mathrm{H}_{2} \mathrm{SO}_{4}$ & 60 & 2.5 & 68.9 & 0.074 & 0.44 & 0.08 & 0.01 & 58.2 \\
\hline \multirow[t]{3}{*}{ Ore 5} & $1 \mathrm{M} \mathrm{H}_{2} \mathrm{SO}_{4}$ & $\mathrm{R} \mathrm{T}$ & 1.4 & 68.5 & 0.093 & 0.43 & 0.07 & 0.01 & 46.9 \\
\hline & $1 \mathrm{M} \mathrm{H}_{2} \mathrm{SO}_{4}$ & 60 & 2.5 & 68.9 & 0.074 & 0.44 & 0.08 & 0.01 & 58.2 \\
\hline & $1 \mathrm{M} \mathrm{H}_{2} \mathrm{SO}_{4}$ & B Pt & 26.1 & 68.5 & 0.050 & 0.05 & $<0.05$ & 0.03 & 78.6 \\
\hline
\end{tabular}

$* \mathrm{BPt}=$ Boiling Point and $\mathrm{R} \mathrm{T}=$ Room Temperature (around $21^{\circ} \mathrm{C}$ ).

$\$$ Weight loss in the leach based on the solids added to the leach and the residue weight.

${ }^{\dagger}$ Based on the head assay, the weight before heating and the residue assay and weight.

tration in the leach and suggest that a leaching temperature of $60^{\circ} \mathrm{C}$ is sufficient to reduce phosphorus levels in the leach product, as was observed with the lower heating temperatures.

Results for heating ore 1 and ore 5 at $900^{\circ} \mathrm{C}$ and leaching with sulphuric acid at 0.5 mass $\%$ solids (Table 5) and 25 mass\% solids (Table 6) show significantly higher levels of phosphorus removal than when the ores were heated at 300 or $350^{\circ} \mathrm{C}$. For example, with a heating temperature of $900^{\circ} \mathrm{C}$ and a leach at 0.5 mass $\%$ solids with $0.5 \mathrm{M} \mathrm{H}_{2} \mathrm{SO}_{4}$, phosphorus levels in ore 5 were lowered to 0.076 mass $\% \mathrm{P}$ compared with 0.118 mass $\% \mathrm{P}$ with the lower heating temperature of $350^{\circ} \mathrm{C}$ (Table 3 ).

About 50 mass $\%$ of the alumina was removed by acid leaching of ore 1 or ore 2 heated at $900^{\circ} \mathrm{C}$, but there was little silica removed in the acid leach (Tables 5 and 6).

The significantly lower weight loss during leaching of ores heated at $900^{\circ} \mathrm{C}$ reflects the lower solubility of the dense hematite phase compared with the ores heated to 300 or $350^{\circ} \mathrm{C}$ (Fig. 2). For example, a leach residue with 0.075 mass $\% \mathrm{P}$ was achieved for the ores with a weight loss of less than 2.5 mass $\%$ (Tables 5 and 6), while with the lower heating temperature of $300^{\circ} \mathrm{C}$ the weight loss was 10 20 mass \%, and less phosphorus was removed (Tables 2 and 3).

\subsection{Acid Recycle Tests}

In a commercial operation, it can be expected that the 
Table 6. Effects on impurity removal from the ore samples of a heat treatment at 300,350 or $900^{\circ} \mathrm{C}$ for $1 \mathrm{~h}$ and a leach with sulphuric acid for $3 \mathrm{~h}$ at 25 mass\% solids.

\begin{tabular}{|c|c|c|c|c|c|c|c|c|c|c|}
\hline \multirow{2}{*}{ Sample } & \multirow{2}{*}{$\begin{array}{l}\text { Heating temp. } \\
\quad\left({ }^{\circ} \mathrm{C}\right)\end{array}$} & \multicolumn{2}{|c|}{ Leaching conditions } & \multirow{2}{*}{$\begin{array}{l}\text { Weight loss }{ }^{\ddagger} \\
\text { (mass } \%)\end{array}$} & \multicolumn{5}{|c|}{ Leached product assays (mass $\%$ ) } & \multirow{2}{*}{$\begin{array}{c}\text { Phosphorus } \\
\text { removed }^{\dagger} \\
(\operatorname{mass} \%)\end{array}$} \\
\hline & & Lixiviant & $\begin{array}{c}\text { Temp. } \\
\left({ }^{\circ} \mathrm{C}\right)\end{array}$ & & $\mathrm{Fe}$ & $\mathrm{P}$ & $\mathrm{SiO}_{2}$ & $\mathrm{Al}_{2} \mathrm{O}_{3}$ & $\mathrm{~S}$ & \\
\hline \multirow[t]{3}{*}{ Ore 1} & & & & & 62.0 & 0.146 & 3.07 & 2.27 & 0.02 & Head sample \\
\hline & 300 & $1 \mathrm{M} \mathrm{H}_{2} \mathrm{SO}_{4}$ & 60 & 7.6 & 63.1 & 0.107 & 3.42 & 2.00 & 0.20 & 34.9 \\
\hline & 900 & $1 \mathrm{M} \mathrm{H}_{2} \mathrm{SO}_{4}$ & 60 & 0 & 5.6 & 0.078 & 3.19 & 1.39 & 0.04 & 49.2 \\
\hline \multirow[t]{3}{*}{ Ore 2} & & & & & 62.1 & 0.123 & 3.22 & 2.18 & 0.02 & Head sample \\
\hline & 300 & $1 \mathrm{M} \mathrm{H}_{2} \mathrm{SO}_{4}$ & 60 & 9.6 & 63.3 & 0.078 & 3.26 & 1.92 & 0.21 & 44.8 \\
\hline & 900 & $1 \mathrm{M} \mathrm{H}_{2} \mathrm{SO}_{4}$ & 60 & 2.2 & 65.9 & 0.067 & 3.36 & 1.08 & 0.04 & 49.4 \\
\hline \multirow[t]{3}{*}{ Ore 5} & & & & & 64.2 & 0.161 & 0.40 & 0.11 & 0.01 & Head sample \\
\hline & 350 & $1 \mathrm{M} \mathrm{H}_{2} \mathrm{SO}_{4}$ & 60 & 5.8 & 67.0 & 0.137 & 0.34 & 0.09 & 0.22 & 24.5 \\
\hline & 900 & $1 \mathrm{M} \mathrm{H}_{2} \mathrm{SO}_{4}$ & 60 & 1.6 & 69.3 & 0.071 & 0.42 & 0.08 & 0.01 & 59.5 \\
\hline
\end{tabular}

* Weight loss in the leach based on the solids added to the leach and the residue weight.

${ }^{\dagger}$ Based on the head assay, the weight before heating and the residue assay and weight.

Table 7. Sulphuric acid leaching recycle tests* on heated ore samples.

\begin{tabular}{|c|c|c|c|c|c|}
\hline \multirow{2}{*}{$\begin{array}{c}\text { Recycle } \\
\text { no. }\end{array}$} & \multirow{2}{*}{$\begin{array}{l}\text { Weight } \\
\text { loss }^{\ddagger} \\
(\operatorname{mass} \%)\end{array}$} & \multicolumn{2}{|c|}{$\mathrm{XRF}$ product assay } & \multicolumn{2}{|c|}{ ICP solution assay } \\
\hline & & $\begin{array}{c}\mathrm{P} \\
(\mathrm{mass} \%)\end{array}$ & $\begin{array}{c}\mathrm{Fe} \\
(\mathrm{mass} \%)\end{array}$ & $P(g / L)$ & $\begin{array}{c}\mathrm{Fe} \\
(\mathrm{g} / \mathrm{L})\end{array}$ \\
\hline \multicolumn{6}{|c|}{ Leaches on ore 2 heated at $350^{\circ} \mathrm{C}$} \\
\hline 0 & 10.5 & 0.072 & 63.8 & 0.22 & 24.2 \\
\hline 1 & 7.0 & 0.083 & 63.4 & 0.39 & 40.9 \\
\hline 2 & 1.7 & 0.096 & 63.4 & 0.55 & 52.7 \\
\hline 3 & 10.0 & 0.076 & 63.3 & 0.83 & 80.9 \\
\hline 4 & 4.8 & 0.082 & 62.4 & 1.04 & 134.0 \\
\hline Average & 8.1 & $0.078^{\#}$ & 63.3 & 0.21 & 26.8 \\
\hline \multicolumn{6}{|c|}{ Leaches on ore 5 heated at $900^{\circ} \mathrm{C}$} \\
\hline 0 & 0.55 & 0.099 & 68.8 & 0.26 & 0.40 \\
\hline 1 & 0.80 & 0.101 & 69.0 & 0.52 & 0.78 \\
\hline 2 & 1.1 & 0.099 & 69.0 & 0.78 & 1.20 \\
\hline 3 & 0.50 & 0.100 & 68.9 & 1.03 & 1.59 \\
\hline 4 & 0.25 & 0.096 & 69.1 & 1.07 & 1.94 \\
\hline Average & 0.65 & 0.099 & 69.0 & 0.21 & 0.39 \\
\hline
\end{tabular}

* Ore 2 was heated at $350^{\circ} \mathrm{C}$ for $1 \mathrm{~h}$ and initially leached at $60^{\circ} \mathrm{C}$ with $1 \mathrm{M}$ $\mathrm{H}_{2} \mathrm{SO}_{4}$ at 25 mass $\%$ solids for $3 \mathrm{~h}$. Ore 5 was heated at $900^{\circ} \mathrm{C}$ for $1 \mathrm{~h}$ and initially leached at room temperature with $1 \mathrm{M} \mathrm{H}_{2} \mathrm{SO}_{4}$ at 25 mass $\%$ solids for $3 \mathrm{~h}$. Before each recycle leach, extra conc. $\mathrm{H}_{2} \mathrm{SO}_{4}$ was added to return to the initial acid concentration conditions.

Weight loss in the leach based on the solids added to the leach and the residue weight.

\# Excluding the value for the recycle 2 leach with the low acid addition.

leach liquors would be recycled several times to leach fresh heated ore to minimise water requirements for the plant and reduce acid consumption. In order to determine whether phosphorus salts might precipitate from solution in subsequent leaches, the heated ores were leached with sulphuric acid and then the leach liquor was used for another four (recycle) leaches. Results for the recycle leaches on ore 2 heated at $350^{\circ} \mathrm{C}$, and ore 5 heated at $900^{\circ} \mathrm{C}$, are presented in Table 7.

Ore 2, was leached at $60^{\circ} \mathrm{C}$ with recycled liquor to which concentrated sulphuric acid was first added to return the $\mathrm{pH}$ of the liquor to a value of $\mathrm{pH} 0.1$. The results in Table 7 show that four leaches had an average product phosphorus level of 0.078 mass $\% \mathrm{P}$ with an average weight loss of $8.1 \mathrm{mass} \%$ and the phosphorus levels in solution increased to $1 \mathrm{~g} / \mathrm{L} \mathrm{P}$ without any indication of phosphorus precipitation. An iron level of $134 \mathrm{~g} / \mathrm{L}$ Fe was measured in the final solution sample, corresponding to an average of $26.8 \mathrm{~g} / \mathrm{L} \mathrm{Fe}$ dissolved in each leach (Table 7). The average acid addition for each of the recycle leaches was $120 \mathrm{~kg} \mathrm{H}_{2} \mathrm{SO}_{4} / \mathrm{t}$ ore.

After heating at $900^{\circ} \mathrm{C}$, recycle leaches on ore 5 at room temperature with the $\mathrm{pH}$ returned to 0.1 prior to each leach gave an average phosphorus content of 0.099 mass $\% \mathrm{P}$ in the leach products, with an average weight loss of only 0.65 mass $\%$ and again the solution assays did not indicate any precipitation of phosphorus during the leaches up to a concentration of $1 \mathrm{~g} / \mathrm{L} \mathrm{P}$ in solution. The average solution assay for iron for each leach was low $(0.39 \mathrm{~g} / \mathrm{L} \mathrm{Fe})$, reflecting the small weight losses in the leach (Table 7). The average acid addition for each of the recycle leaches was $90 \mathrm{~kg}$ $\mathrm{H}_{2} \mathrm{SO}_{4} / \mathrm{t}$ ore.

It is interesting to note that a lower acid consumption was measured for the ore heated at $900^{\circ} \mathrm{C}$ compared with that for the ore heated to $300^{\circ} \mathrm{C}$. It is anticipated that the acid consumption will be significantly lower if the recycle tests were conducted at a $\mathrm{pH}$ of 0.5 that has been shown to give acceptable phosphorus removal (Table 4 ).

\section{Discussion}

The results presented here indicate that phosphorus levels can be lowered in goethitic iron ores by leaching with sulphuric acid after a heat treatment. The final phosphorus levels achieved for each ore were related to the temperature at which the ore was heated, the concentration of acid in the leach, the temperature of the leach, the amount of phosphorus required to be removed from the ore, and the solubility of other phases in the ore. Leaching at the higher pulp density required a higher acid concentration to meet equivalent residual phosphorus levels.

The heating treatment results in dehydration of the 
goethite and its conversion, through several intermediate phases, to a dense hematite phase. A schematic sequence of the conversion has been presented ${ }^{16)}$ with decomposition of synthetic goethite commencing at $150^{\circ} \mathrm{C}$ and transforming first into 'protohematite' (in a temperature range of 250$\left.400^{\circ} \mathrm{C}\right)$, then to 'hydrohematite' $\left(430-700^{\circ} \mathrm{C}\right)$ and ultimately to hematite (above $800^{\circ} \mathrm{C}$ ). In the samples used in this study, XRD patterns indicated that the conversion of goethite to protohematite had commenced at $250^{\circ} \mathrm{C}$ and was substantially complete after $30 \mathrm{~min}$ at $300^{\circ} \mathrm{C}$. )

For nickel laterite ores containing nickel associated with the goethite component of the ore, it has been found ${ }^{17)}$ that dissolution of iron and nickel was significantly increased in acid leaches after heating the ores at temperatures of 340 $400^{\circ} \mathrm{C}$. It was proposed ${ }^{17)}$ that the increase in metal dissolution was partly due to an increase in surface area from the development of micropores as a result of dehydroxylation of the goethite during the heating, and partly to an overall increase in structural disorder.

Removal of phosphorus from goethitic iron ores after heating at $300-350^{\circ} \mathrm{C}$ is anticipated to follow a similar mechanism. The increase in both the porosity and the structural disorder of the iron phase on heating results in increased reactivity of the phosphorus-containing iron oxide phase. The high weight loss during leaching (Fig. 2) indicate that this phase is dissolved in the acid along with the phosphorus. On heating at $900^{\circ} \mathrm{C}$ the goethite is converted to a dense hematite phase that has a low solubility in acid, and this results in dissolution of phosphorus with little weight loss.

Ore 1 and ore 2 contained appreciable levels of silicon and aluminium. While silicon was not removed in the acid leaches, up to 50 mass \% of the aluminium was removed. This suggests that some of the aluminium may be associated with phosphorus in the goethite, as proposed by MacRae and co-workers. ${ }^{18)}$

Obtaining leach products with 0.075 mass $\% \mathrm{P}$ from ores heated at 300 or $350^{\circ} \mathrm{C}$ resulted in dissolution of iron oxides in the sample with iron levels of around $25 \mathrm{~g} / \mathrm{L} \mathrm{Fe}$ in the leach liquors (ore 2), an associated sample weight loss of $10-20$ mass $\%$. Leaching ore heated at $900^{\circ} \mathrm{C}$ under similar acid conditions resulted in better phosphorus removal with little dissolution of iron oxides and a lower acid consumption.

The economics of a process with a lower heating temperature but requiring higher acid consumption and treatment of the increased amounts of iron in solution, compared with a higher heating temperature and little iron dissolution during the leach will be a significant consideration in determining the best commercial operating conditions.

\section{Summary}

The results of the effects of thermal transformations of goethite in iron ores on the removal of phosphorus from Australian iron ores with a sulphuric acid leach have been presented in this paper.

The study demonstrated that a low temperature heat treat- ment at 300 or $350^{\circ} \mathrm{C}$ and a sulphuric acid leach process reduced the phosphorus levels in the ore to below 0.075 mass $\% \mathrm{P}$, but this was associated with appreciable levels of iron in the leach liquor and high acid consumption. Heating to about $350^{\circ} \mathrm{C}$ is considered to result in conversion of the phosphorus-containing goethite to a hematite intermediate phase, protohematite, that was readily soluble in the sulphuric acid along with the phosphorus.

Increasing the heating temperature to $900^{\circ} \mathrm{C}$ improved phosphorus removal in the leach. Heating at $900^{\circ} \mathrm{C}$ transformed the goethite to a dense hematite phase that has a low solubility in the acid and enabled phosphorus removal with little dissolution of iron and lower acid consumption.

The best operating conditions are likely to depend on balancing the benefits of a lower heating temperature with dissolution of appreciable amounts of iron oxides compared with a higher heating temperature but with low levels of iron in the leach liquors levels.

\section{Acknowledgements}

The assistance of CSIRO colleagues at Clayton, in particular Daniela Polidori and Steve Peacock for XRF analyses, Chris Sheedy for ICP analyses and Nicki Agron-Olshina for identification of the minor phases in the XRD patterns are gratefully acknowledged.

\section{REFERENCES}

1) V. S. Dub, A. V. Dub and E. V. Makarycheva: Metal Sci. Heat Treat., 48 (2006), 29.

2) D. C. Fonseca, C. C. Souza and A. C. Araujo: Sutulov Memorial Volume, Vol. III Chemical Metallurgy, IV Meeting of the Southern Hemisphere on Mineral Technology, ed. by I. Wilkomirsky, M. Sánchez and C. Hecker, Universidad de Concepción, Concepción, Chile, (1994), 83.

3) C. Y. Cheng, V. N. Misra, J. Clough and R. Mun: Miner. Eng., 12 (1999), 1083.

4) W. Thorne, S. Hageman, A. Webb and J. Clout: SEG Rev., 15 (2008), 197.

5) M. J. Fisher-White, R. R. Lovel and G. J. Sparrow: ISIJ Int., 52 (2012), 797.

6) E. R. Ramanaidou: Personal communication, (2010).

7) R. D. Dukino, B. M. England and M. Kneeshaw: Trans. Inst. Min. Metal. (Sect. B: Appl. Earth Sci.), 109 (2000), B168.

8) M. A. Wells and E. R. Ramanaidou: Iron Ore 2011, The Australasian Institute of Mining and Metallurgy, Melbourne, (2011), 331.

9) R. D. Dukino and B. M. England: Ironmaking Resources and Reserves Estimation, The Australasian Institute of Mining and Metallurgy, Melbourne, (1997), 197.

10) M. J. Fisher-White, R. R. Lovel and G. J. Sparrow: Iron Ore 2009, The Australasian Institute of Mining and Metallurgy, Melbourne, (2009), 249.

11) G. B. Peixoto: International Patent Application, (1993), WO 93/ 10271.

12) J. E. A. Gooden, W. M. Walker and R. J. Allen: Proc. of 2nd Natl. Chemical Engineering Conf., The Institution of Chemical Engineers, University of Queensland, St. Lucia, (1974), 38.

13) T. R. C. Patrick and R. R. Lovel: ISIJ Int., 41 (2001), 128.

14) I. L. Feld, T. W. Franklin and W. M. Lampkin: US patent, (1968), 3, 402, 041.

15) C. I. Edwards, M. J. Fisher-White, R. R. Lovel and G. J. Sparrow: Iron Ore 2011, The Australasian Institute of Mining and Metallurgy, Melbourne, (2011), 403.

16) M. A. Wells, R. W. Fitzpatrick and R. J. Gilkes: Clays Clay Miner., 54 (2006), 176.

17) M. Landers, R. J. Gilkes and M. Wells: Appl. Clay Sci., 42 (2009), 615.

18) C. M. MacRae, N. C. Wilson, M. I. Pownceby and P. R. Miller: Iron Ore 2011, The Australasian Institute of Mining and Metallurgy, Melbourne, (2011), 281. 